\title{
Establishing The Link Between Money Laundering And Tax Evasion
}

\author{
Ansia Storm, Northwest University, Potchefstroom, South Africa
}

\begin{abstract}
No clear link has yet been made between tax evasion and money laundering although many (or all) of the professionals in this field may have already assumed the relation. The aim of the research that was conducted for the purposes of this article was to explore whether there is a clear link between tax evasion and money laundering. This was done by studying the relevant literature available on both subjects. The findings, that there is a clear link between these two offences, were confirmed not only by analyzing definitions but also, and most importantly, by an overview of court cases and the judgments made in these court cases. In theory, the results have proven that one cannot look at money laundering without considering tax evasion as well but tax evasion does not necessarily constitute the act of money laundering. This is of value to the individuals and organizations working in the field of taxation and organized crime, because when prosecuting a perpetrator on a count of money laundering, by adding the charge of tax evasion to his or her charge sheet, it can strengthen the case against the accused.
\end{abstract}

Keywords: Tax Evasion; Money Laundering

\section{INTRODUCTION}

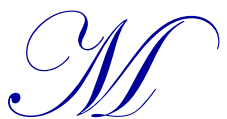

oney makes the world go round and this may be the reason why it is widely believed that tax evasion and money laundering will be the demise of all economies. Recently, Greece made headlines in the news because of their failing economy (Dugdale, 2012, p. 1). Following that news break, The Guardian reported that "Greece is not alone - tax evasion is a British problem too". A few months after Greece made headlines, Crumley (2012) reported that Italy, Spain and Portugal were only delaying their banishment in the undesirable zone. Tavares $(2013$, p. 2) also wrote of the euro crisis where "several countries have been submitted to international bailout programs" in his thematic paper on money laundering.

Money laundering, the name given to the act of filtering ill-gotten gains or 'dirty' money, is said to have originated in the time when the Mafia owned laundromats in the United States of America (USA). Laundromats were legal businesses used to legitimize huge sums of cash from extortion, gambling, bootleg liquor and prostitution. This was done by blending the illegal gains with the earnings received by these laundromats. Something that made these laundromats to be of an indubitable advantage was the fact that they were cash businesses. Although Al Capone was convicted for tax evasion, his conviction may have been the trigger for lifting the money laundering business off the ground (Dadoo, 2012; Krishna, 2008; “Al Capone: Biography", 2012).

It is said that $\mathrm{Al}$ Capone did not trust banks - he never had a bank account and conducted all of his financial transactions in cash. The Internal Revenue Service (IRS) could not even find a single transaction where Al Capone purchased securities. Although the authorities knew that Al Capone was behind most of the murders that took place during his reign as mafia boss, no evidence could ever be found or brought against Capone. Thus, the federal government made a two-pronged attack plan: collecting evidence of Prohibition Law violations and collecting evidence of Capone not paying taxes on his income. The IRS found an incriminating ledger and some witnesses who were able to testify against Capone on tax evasion. He was charged with 22 counts of tax evasion and 5000 violations of the Prohibition Law. Later Capone was found guilty on only five of the tax evasion charges (Krishna, 2008; “Al Capone: Biography”, 2012). After the conviction and incarceration of Capone, Meyer Lansky, who was also called 'The Mob's Accountant', was afraid that the same fate would befall him, thus he started 
searching for a better way to launder money and evade taxes. Lansky discovered the benefits of numbered Swiss Bank accounts - starting the culture of money laundering - and went on to become one of the most influential money launderers of all time (Krishna, 2008; Dadoo, 2012).

The United Nations Office on Drugs and Crime (UNODC) estimated that the amount of money laundered globally in one year is $2-5 \%$ of global gross domestic product (GDP), or $\$ 800$ billion $-\$ 2$ trillion in current US dollars, and commented: "Though the margin between those figures is huge, even the lower estimate underlines the seriousness of the problem governments have pledged to address" ("Money-Laundering and Globalization, 2012").

Although research has been done on both tax evasion and money laundering, no research could be found that pertinently established the link between tax evasion and money laundering. The research conducted established how these two offences relate to each other. The focus of the research was on an international and local level because tax evasion and money laundering is a world-wide problem. The findings of the research are discussed in the following paragraphs.

\section{TAX EVASION AND MONEY LAUNDERING}

As previously mentioned, no literature was found that significantly established the link between tax evasion and money laundering. The scope and the focus of the literature review were mainly on applicable legislation, court cases, legal definitions, scholarly articles, reports published by applicable organizations and news headlines. To establish whether or not there is a link between tax evasion and money laundering, the literature was analyzed and the findings are discussed in the paragraphs that follow. The court cases were also studied and the relation between the court cases and literature are subsequently discussed and the relevant conclusions are indicated.

From the paragraph above it is clear that the aim of the research was to determine whether a link exists between tax evasion and money laundering. As a prelude to the arguments around establishing the link, there will be a brief discussion in the following section about some of the literature found on the link between tax evasion and money laundering.

\section{The Link between Tax Evasion and Money Laundering}

Tavares's (2013) thematic paper focused on the extent and context of the crime, the societal aspects of the fight against money laundering and tax evasion, tax evasion as a multi-faceted challenge, tax havens and interlinking policy fields in relation to tax havens. Unger (2009) only touched on the "precarious relation" between these two offences before it took a mathematical approach to measure money laundering and tax evasion. Although these two authors took two different approaches in their articles, the focus of this article will be on literature and not on mathematical approaches as the latter is perceived to be a subject for later research.

Spreutels and Grijseels (2010) discussed tax evasion as a predicate offence for money laundering and looked at, amongst other things, the different legislation and the consequences that resulted from the Organization for Economic Co-operation and Development (OECD) Council Meeting held in 1998. Oliver (2002), who looked at tax evasion as a predicate offence to money laundering, considered international taxation and the hotchpotch of laws in Britain that addressed the issues of money laundering and tax evasion. Taking the above-mentioned articles into consideration, it can be stated that the perception of tax evasion being linked to money laundering has existed for some time now. Later in the article, the court cases studied will show that where the accused were charged for money laundering, the charge of tax evasion was also added to the list of offences.

There are two important concepts featuring in this article, namely tax evasion and money laundering. The first discussion will be on tax evasion and what it entails and then the discussion on money laundering will follow.

\section{TAX EVASION}

As previously stated, the concept of tax evasion is a key element in this article. Various definitions of tax evasion are available. A few of these definitions will be given to establish common ground for the rest of this 
section. Tax evasion is an illegal practice where there is an intentional avoidance to pay the true tax liability. The perpetrators who are caught evading taxes are generally subject to criminal charges and substantial penalties (Stiglingh, 2013, p. 773). For criminal charges to be brought against someone, a crime had to be committed. In order to link tax evasion to the term 'crime', the definition of crime together with the analysis of the descriptions of tax evasion and crime will be discussed in the following paragraph.

A crime is an illegal or unlawful activity, a violation of a law in which there is injury to the public or a member of the public and a term of jail or prison and or fine as possible penalties exists (Smith, 2012). The definitions of tax evasion and crime indicate that both are illegal practices. Another characteristic that can be derived from the definitions of tax evasion and crime is that by evading taxes there is 'injury' to the public. This 'injury' occurs when there is not enough money to be set aside by the government to improve hospitals, police force efficiency and education, to name but a few government responsibilities. Thus, the public becomes the party who suffers at the hands of the tax evaders. Now that tax evasion has been defined and analyzed together with the definition of crime, a few activities that can be classified as tax evasion can be discussed.

These activities include the refusal to file a tax return, deducting more than one actually spent, claiming credits one is not entitled to and lying on one's tax return (Marquit, 2012, par 5; www.austrac.gov.au). For the purpose of this research, the most important activities of tax evasion were deemed to be the failure to report all of one's income, offshore bank accounts and/or foreign income. The reason for this statement is that failing to report all one's income, offshore bank accounts and/or foreign income can or possibly may constitute money laundering.

In identifying the most important activities of tax evasion with regard to possible money laundering practices, the proof that a link exists between these two offences is strengthened.

It has been stated that by evading taxes, there is 'injury' to the public. To demonstrate the degree of tax evasion, Tax Justice Network compiled a table in 2011. The names of six countries with the highest tax evasion cases were given, the total amount of the tax evaded and the percentage of the tax evasion with relation to the global gross domestic product (see Table 1).

Table 1: Tax Evasion as a Percentage of the Global Gross Domestic Product

\begin{tabular}{|l|c|c|}
\hline \multicolumn{1}{|c|}{ Country } & US \$ & \% of Global Gross Domestic Product \\
\hline United States & $337,349,000,000$ & $8.6 \%$ \\
\hline Bolivia & $3,727,000,000$ & $66.1 \%$ \\
\hline Russia & $221,023,000,000$ & $43.8 \%$ \\
\hline Italy & $238,723,000,000$ & $27.0 \%$ \\
\hline Greece & $30,791,000,000$ & $27.5 \%$ \\
\hline Ireland & $9,922,000,000$ & $15.8 \%$ \\
\hline
\end{tabular}

The above-mentioned figures prove the magnitude of tax evasion as well as the fact that tax evasion is an international problem, as emphasized by Dugdale (2012): "Tax evasion has been an endemic problem in the developing world for many years, but as more and more countries struggle to balance their budgets it has become an extremely prescient issue in the developed world as well." Murphy (2011) commented that "[tax evasion is] a crime against the people" after compiling a report for the British NGO Tax Justice Network on tax fraud in November 2011. Murphy further argued that tax evasion by wealthy individuals and/or corporations often shift the burden of paying for public services or debt to the poorest members of society (Foreign Policy, 2012 par. 2). To substantiate Murphy's statement, a list of international and local celebrities that have been indicted and in some instances incarcerated for tax fraud was compiled. Some of these public figures are mentioned below.

1. The actor Wesley Snipes served a three-year jail sentence in America for tax evasion (Friedman, 2010). He was released from jail on 2 April 2013 and is currently under house arrest, which will end 19 July 2013 (Oldenburg, 2013).

2. The former prime minister of Italy, Mr Silvio Berlusconi, was convicted of tax fraud and sentenced to four years in prison (Blake \& Pisa, 2012). However, Berlusconi appealed the court's decision and the court agreed to adjourn his appeal for one month (Reuter's, 2013). This appeal will continue on 20 April 2013. 
3. In South Africa, the former ANC Youth League president, Julius Malema, faced charges of tax evasion and corruption (Bauer, 2012). He was found guilty on tax evasion charges and the South African Revenue Services calculated the tax owed by Malema to be R16.1 million.

4. Mr Jacob Zuma faced 16 counts of fraud, corruption and tax evasion but the charges were dropped in 2009 just before he became president of the Republic of South Africa (Conway-Smith, 2012).

5. The French minister tasked with battling tax fraud, Mr Jerome Cahuzac, resigned after allegations of tax fraud and money laundering (Samuel, 2013).

The list goes on and it seems as if the people who have to set the example are in fact the perpetrators. One may ask whether this is why tax crimes never attract much attention or muster substantial political will to counteract their occurrence.

Tax evasion, its magnitude as well as how it links to crime have been discussed in the previous paragraphs. The next step in the attempt to link tax evasion with money laundering is a discussion on money laundering itself.

\section{MONEY LAUNDERING}

As is the case with tax evasion, various definitions exist for money laundering. In order to bring money laundering into perspective and further strengthen the argument of the existence of a link with tax evasion, a few of these descriptions will be given before analyzing this concept. Money laundering is "the activity which has or is likely to have the effect of concealing or disguising the nature, source, location, disposition or movement of the proceeds of unlawful activities or any interest which anyone has in such proceeds, and includes any activity which constitutes an offence" (The Prevention of Organized Crime Act No 121 of 1998). "Money laundering is a criminal offence aimed at presenting wealth of illicit origin or the portion of wealth that has been illegally acquired or concealed from the purview of tax and other authorities, as legitimate, through the use of methods that obscure the identity of the ultimate beneficiary and the source of the ill-gotten profits" (Tavares 2013). Money laundering is "a complicated activity in which the source and the nature of the money are disguised in order to make the money look lawful and then become usable, transferable and negotiable" (He, 2010). From the definitions provided above, it appears as if money laundering is seen as any act or attempted act to disguise the source of the money or assets derived from criminal activity. Now that the term 'money laundering' has been clarified, the next step will be to analyze the various definitions of this term and compare them to the various explanations given in the previous paragraphs with regard to tax evasion.

The following commonalities were identified by comparing the definitions of tax evasion and money laundering: both are unlawful activities; both involve the violation of laws; the acts are deliberate in both tax evasion and money laundering; and both of these offences disguise or conceal the money received. It was necessary to analyze the definition of tax evasion in terms of a crime because it has frequently been argued that the proceeds of tax evasion are different to the proceeds of conservative criminality. One of those arguments is that since the underlying conduct that generated the profit was legal, the non-payment of the subsequent tax on those profits could not be equated to the proceeds of criminal conduct. A counter-argument, however, is that although the underlying conduct is legal, the retention of money that should be paid over as tax is the actual criminal conduct (Oliver, 2002, p57). One can take Oliver's argument a step further and state that where tax evasion is involved, it does not automatically indicate money laundering. However, where money is being laundered, the chances of tax evasion being part of the equation are perceived to be $100 \%$.

Another way of proving that a link exists between tax evasion and money laundering is to take a look at the reasons why criminals launder money. Some of the reasons are that they are trying to hide wealth; they want to evade taxes in order to increase their profits; they want to legalize the money and they want to avoid prosecution. An interesting point is that according to the South African Income Tax Act No 58 of 1962, an individual is obliged to pay taxes on his/her earnings irrespective of where the earnings come from. Thus, illegal funds must be declared to the South African Revenue Services. However, this never happens because of the risk of being prosecuted for the offence of money laundering and/or other applicable offences.

To further prove the link between money laundering and tax evasion, one can name a few of the consequences there are to laundering money. Firstly, money laundering undermines financial systems by expanding 
the segment of a country's economic activity that is derived from sources, legal or illegal, that fall outside of the country's rules and regulations regarding commerce. Secondly, it promotes crime because it enables criminals to use and deploy illegal funds effectively. Lastly, the most important consequence is that money laundering reduces revenue and control by diminishing government tax revenue and weakening government control over the economy, causing 'injury' to the public.

Since illicit financial flows are just one of the systems which involve the laundering of money from illgotten gains, the concept of illicit financial flows is discussed in the following section. This will not only explain one of the systems through which money is laundered, but it will also prove how illicit financial flows assist in the evasion of taxes.

\section{The Role of Illicit Financial Flows in Money Laundering and Tax Evasion}

Illicit financial flows are discussed in this section is to explain one of the systems through which money is laundered and to prove how it assists in tax evasion. The cross-border movement of money that is illegally earned, transferred, or utilized, is referred to as the flow of illicit funds (Renner, 2012). This usually involves the transfer of money earned through illegal activities, for example criminal deeds (money laundering) and corruption, as well as efforts to hide wealth from a country's tax authorities. Deriving from this explanation of illicit financial flows, it can be stated that the offences of both money laundering and tax evasion are included in illicit financial flows. The question surrounding the magnitude of the flow of illicit funds was raised during the research. Figure 1 illustrates the growth in the flow of illicit funds between 2001 and 2010 (Illicit Financial Flows December 2012 report).

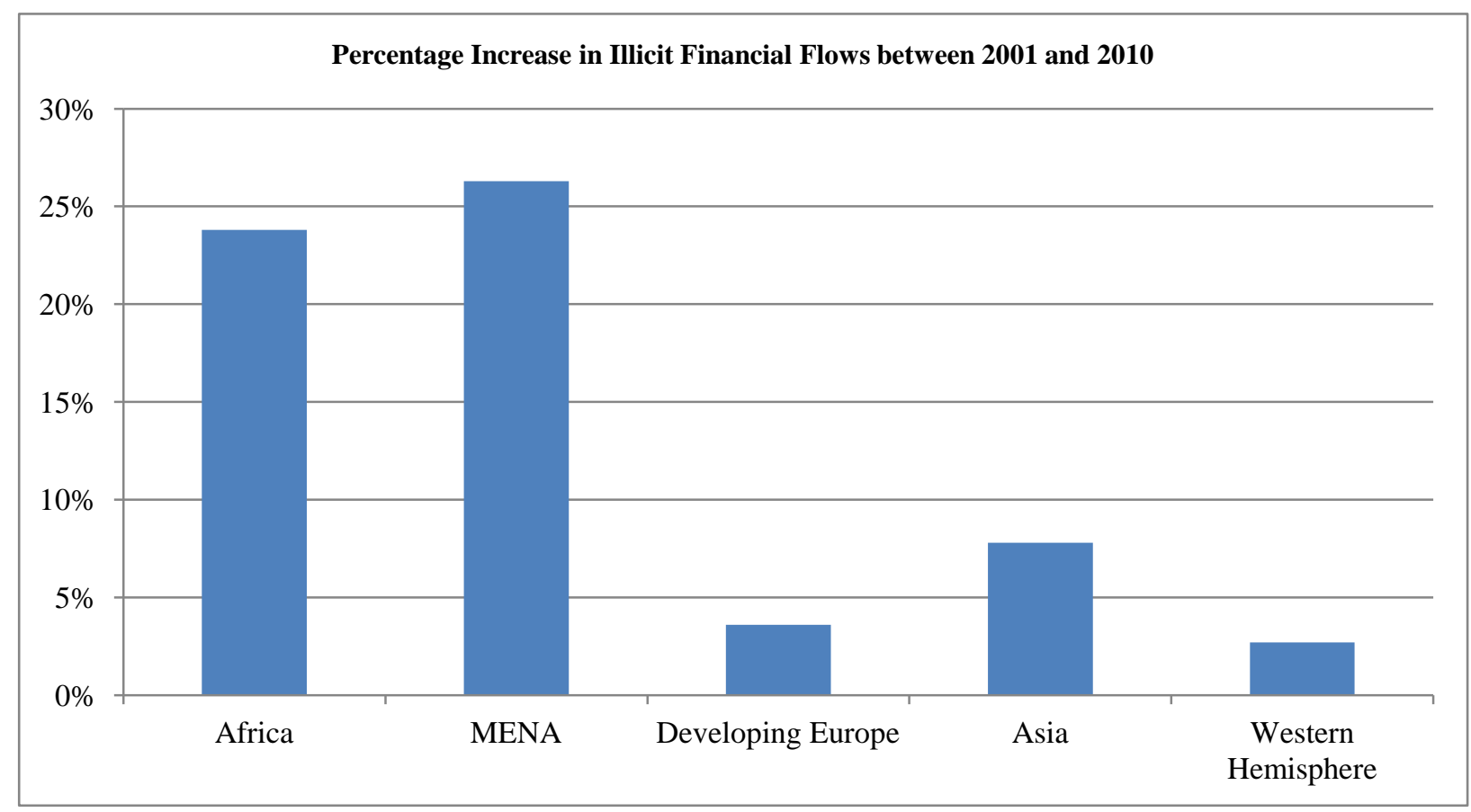

Figure 1: Primary Findings of Global Financial Integrity (2012)

The results shown in Figure 1 prove the statement that the flow of illicit financial funds is problematic for some developing countries. Money laundering and tax evasion have already been included in the term 'illicit financial flows', thus this is yet another way of putting the problem of money laundering and tax evasion into perspective. To quantify this problem, the same primary findings in the Global Financial Integrity report of 2012 showed that developing countries lost US\$859 billion in illicit financial flows in 2010. In total, for the period 20012010, developing countries lost US\$5.86 trillion to illicit financial outflows. The question was raised to identify the countries with the highest measured cumulative illicit flows between 2001 and 2010 in order to bring the data 
provided in Table 2 into perspective. In Table 2 the top 10 countries are listed together with the total cumulative illicit financial flow.

Table 2: The Top 10 Countries with the Highest Illicit Financial Flows

\begin{tabular}{|l|c|}
\hline \multicolumn{1}{|c|}{ Country } & Cumulative Illicit Financial Outflow \\
\hline China & US\$2.74 trillion \\
\hline Mexico & US\$476 billion \\
\hline Malaysia & US\$285 billion \\
\hline Saudi Arabia & US\$210 billion \\
\hline Russia & US\$152 billion \\
\hline Philippines & US\$138 billion \\
\hline Nigeria & US\$129 billion \\
\hline India & US\$123 billion \\
\hline Indonesia & US\$109 billion \\
\hline United Arab Emirates & US\$107 billion \\
\hline
\end{tabular}

The data provided in Table 2 correlates with the information shown in Figure 1. Most of the countries listed in Table 2 are in the Middle East and Northern Africa (MENA), Africa and the Western Hemisphere. South Africa was ranked in the $12^{\text {th }}$ place with a cumulative illicit financial flow of US $\$ 8.39$ billion. That is US $\$ 839$ million each year that is lost to the South African government and that could have been used to improve the South African infrastructure.

In the previous section, one of the methods of laundering money was discussed and quantified. The magnitude of illicit financial flows has been discussed and it was stated that illicit financial flows includes the offences of evading taxes and laundering money. However, perpetrators seldom work alone and most of the time help is needed to move the money or to legitimize it. The role that banking institutions play in facilitating money laundering and tax evasion is discussed in the following section.

\section{BANKING INSTITUTIONS: TAX EVASION AND MONEY LAUNDERING MADE EASY?}

In the previous paragraph it was stated that money launderers and tax evaders do not work alone. This claim is substantiated by the following: interview:

Firstly, Detective Superintendent Des Bray of the Commercial and Electronic Crime Branch stated in an

What is being increasingly identified is the infiltration of criminal identities into otherwise legitimate business interests. None of these people could get away with it a lot of what they were doing if it wasn't for lawyers, accountants, financial advisors and the like, knowingly assisting them to launder and hide assets.

Secondly, since bank secrecy is being upheld by most or all of the banks tax evasion (and even money laundering) is made easy because the strict bank secrecy rules prevent the exchange of information with the individual's country of residence. This makes it difficult for the domestic tax authorities to track capital income. He (2010) specifically refers to the use of banking institutions for money laundering purposes. It was found to be a popular route to follow, as it is convenient and quick to transfer funds across international borders. Since bank secrecy exists in almost every country financial institutions are very vulnerable to money laundering (He, 2010). Bank secrecy enables criminals to cover up or conceal the nature and source of the illegally obtained proceeds, thus evading taxes at the same time. A good example is that of three Zurich-based bankers who were charged with helping US taxpayers hide approximately $\$ 1.2$ billion from the Internal Revenue Service. These three bankers now face up to five years in prison because they allegedly helped more than 100 clients between 2005 and 2010 hide assets (O’Toole, 2012).

The banking institutions that are involved are not necessarily institutions within the resident's country, as Owens (2007) points out: 
Offshore tax evasion is not about small islands that do not impose income taxes: it is about all the countries [for example Liechtenstein], that lack transparency and that are not prepared to cooperate to counter tax abuse. These practices make it difficult for other countries [for example USA] to enforce their own tax laws.

Countries can no longer rely on their own sources of information to ensure compliance with their domestic tax laws. Prosperous individuals easily evade income taxes in their country by transferring capital to offshore jurisdictions. Even money launderers can now legitimize their ill-gotten gains.

As mentioned previously, Owens used the term "small islands" which implies that such countries are seen as tax havens, depending on the tax levied by those "small islands". This term leads to the following discussion on tax havens and offshore accounts.

\section{TAX HAVENS AND/OR OFFSHORE ACCOUNTS}

This discussion is aimed at shedding light on the internationalism of money laundering and tax evasion. The international press lumps together tax havens and offshore financial centers, focusing on their facilitation of money laundering, tax evasion and other financial crimes (Rider, 2009). The most common place to hide money or to launder money - in other words for purposes of tax evasion - is in an offshore account in a tax "haven". A haven can be described as being "autonomous or semi-autonomous jurisdictions offering a combination of lax legislation, low or zero taxation on income and capital of non-residents, secrecy facilities for banking or corporate ownership, and absence of effective information exchange with the authorities of third party countries" (Christensen, p. 1).

According to the Organization for Economic Co-operation and Development, four factors are used to determine whether a jurisdiction is a tax haven. These four factors are the existence of no or nominal taxes, the lack of transparency, the prevention of the effective exchange of information for tax purposes and an absence of a requirement that the activity must be substantial. The exchange of information mentioned here is between other governments on taxpayers benefiting from the no or nominal taxation. These four factors are substantiated in Christensen's (2011) definition of a tax haven. Tax havens have become major providers of operational bases used by financial professionals and their clients to take advantage of legislative gaps and laidback regulation for grandscale corruption. They encourage and enable tax evasion as well as capital flight and they facilitate illicit financial flows which originate from the proceeds of corruption.

Another reason why offshore accounts are such popular destinations is that, just like most banks, they still argue or uphold client privacy when confronted with the violation of legislation. Even when faced with the new Financial Account Tax Compliance Act adopted by the USA in March 2010, some of these tax havens do not want to co-operate ("FATCA - Tax Risks for US Investments").

The provision of conditions of secrecy which is created through banking secrecy laws or de facto judicial arrangements and banking practices is the most defining characteristic of tax havens. This characteristic, which might be the biggest reason for launderers to use tax havens, is also an effective barrier to investigators wanting to investigate activities that were booked through the tax haven. These provisions for secrecy also assist in the laundering of proceeds of criminal activity (Christensen \& Hampton, 1999b). The proceeds of crime and tax evasion are brought into commercial transactions using multi-jurisdictional structures. Lord Templeton, in the case of AG for Hong Kong v. Reid (1994) 1 All ER 1, stated: "[T] he court must prevented ill-gotten gains being whisked away to some Shangri-La which hides bribes and other corrupt moneys in numbered bank accounts." Because the concerns about tax havens made way for concerns about tax evasion, the G20 announced in 2009 that the "era of banking secrecy is over". The question remains, is it really over? However, this is a question that will require extensive research before it can be answered.

With reference to tax havens and how they assist in tax evasion and money laundering, the statement made by Dugdale (2012) that tax evasion is endemic to the developing world, echoes Christensen's (2011) view that "in many cases the situation has deteriorated because the use of sophisticated offshore structures using secrecy jurisdictions has become very much more widespread in recent decades". 
The Tax Justice Network is an organization that strongly expresses its dislike in tax havens. They address the nature of tax havens are, the corruption they entail and the magnitude of the problem. For instance, the estimated assets held by tax havens are $\$ 11.5$ trillion. This means that tax revenue of $\$ 250$ billion is lost each year ("Tax Havens Cause Poverty", 2010). To further illustrate this so-called "devastation" that tax havens cause, the Tax Justice Network (2010) also issued the following statement:

Countries that lose tax revenues become more dependent on foreign aid. Recent research has shown, for example, that sub-Saharan Africa is a net creditor to the rest of the world in the sense that external assets, measured by the stock of capital flight, exceed external liabilities, as measured by the stock of external debt. The difference is that while the assets are in private hands, the liabilities are the public debts of African governments and their people.

Table 2, which shows the growth in illicit financial flows, also shows that the highest increase was in Africa and the Middle East and Northern Africa (MENA).

To illustrate the ignorance of some governments when it comes to fighting crime, the example of the Liechtenstein affair will be discussed next. In mid-February 2008, it emerged that LGT Bank, a prominent Liechtenstein bank, was under close scrutiny due to allegations of tax evasion. It was later described as the "biggest complex of investigations ever initiated for tax evasion in the Federal Republic of Germany". Liechtenstein is a tax haven with a mere $0.1 \%$ tax on offshore trusts. The way in which this investigation started is interesting. A former LGT employee stole a compact disc containing the names of high-profile suspects and offered it to the UK authorities in 2006. They turned it down. The German authorities, however, snapped it up for 4.2 million euros. Then the investigation began. It was later reported that the USA, Finland, Sweden and the UK were also investigating financial dealings linked to Liechtenstein (Matheza, 2008).

There have been other attempts to tackle illicit financial flows through tax havens but those have been unproductive, mainly because international organizations charged with tackling illicit financial flows have taken a too narrow a definition of what money laundering really is (Christensen \& Spencer, 2008, p. 13).

It is well known that corruption is damaging to the viable development of third world countries, but how tax havens contribute to the privation of these countries is less well known.

The section above demonstrated how tax havens assist perpetrators in tax evasion and money laundering. It also gave evidence of the challenges the world faces in its attempt to eradicate corruption. In the next section, relevant court cases and the judgments that were made are discussed.

\section{INTERNATIONAL AND SOUTH AFRICAN COURT CASES}

In the paragraphs to follow, some of the court cases found in the literature are discussed. This is the last stepping stone in establishing the link between tax evasion and money laundering. No court case could be found where the accused were convicted on counts of evading taxes as well as laundering money, but in all of the court cases mentioned in this discussion the accused were charged with both tax evasion and money laundering.

\section{International Court Cases}

The first court case that will be discussed is that of the owner of the Fruitland Bar in the USA who was sentenced for tax evasion, illegal gambling and money laundering. The United States Department of Justice released a report on the Fruitland Bar owner case on December 5, 2012. Thomas Dale Overstreet (68) was sentenced to 46 months in prison followed by three years of supervised release on counts of income tax evasion, operating an illegal gambling business and conspiracy to commit money laundering.

The second court case in this discussion is that of United States v. Smith, 424 F.3d 992 (9th Cir. 2005). The Ninth Circuit affirmed defendants' convictions for violating 26 U.S.C. § 7206(2), tax fraud; 18 U.S.C. § 1341, mail fraud; 18 U.S.C. $§ 1343$, wire fraud; 18 U.S.C. $\S \S 1956,1957$, money laundering; and 18 U.S.C. $§ 371$, conspiracy. 
In the third court case $\$ 40$ million in assets were restrained because of a tax evasion and money laundering scheme that was uncovered in Australia. As part of Project Wickenby, the Australian Federal Police charged a 67year-old man with conspiring to dishonestly cause a loss to the Australian Tax Office to deal in the proceeds of crime to the value of $\$ 63$ million.

The second to last court case in this discussion is that of Spies v U.S 317 U.S 492, 497 (1943). In this case the Supreme Court observed: “... singly or in combination [in income tax crimes] were calculated [by Congress] to induce prompt and forthright fulfillment of every duty under the income tax law and to provide a penalty suitable to every degree of delinquency". IRC sec 7206(2) a person is guilty of a crime if he or she willfully "aids or assists in or procures, counsels, or advises the preparation or presentation ... of a return, affidavit, claim or other document, which is fraudulent or is false as to any material matter, whether or not such falsity or fraud is with the knowledge or consent of the person authorized or required to present such return, affidavit, claim or documents." Although this case does not refer to money laundering, but only to tax evasion, the observation of the court that needs to be highlighted for the purpose of this article is that a person is considered to be guilty of a crime.

The last court case in this discussion on international court cases is that of Tinkoff $v$ U.S $86, F .2 d 868\left(7^{\text {th }}\right.$ Cir., 1936). In this case an accountant was convicted of tax evasion because he or she prepared fraudulent returns for clients, bringing the attention back to the fact that (sometimes) the perpetrators are trying to make use of the services of lawyers, banking institutions and accountants to assist them in their crimes (and in some instances, succeed in doing so).

In the five court cases discussed in the paragraphs above, in (nearly) all cases where the accused was charged with money laundering, he or she was also charged with tax evasion. It appears as if the authorities had already accepted the link between tax evasion and money laundering when the charges were written up on the charge sheet.

\section{Court Cases in South Africa}

In order to give a balanced viewpoint, the following examples are from South Africa. The first South African court case is that of the National Director of Public Prosecutions (NDPP) v Abrina 6822 Ltd and Others 2011(1) SACR 419 (KZP). This case raised a point about the proper interpretation of s 38 of the Prevention of Organised Crime Act No 121 of 1998 (the Act). The circumstances surrounding this case were that the JA \& F Charnaud Trust conducted farming operations on six properties in KwaZulu-Natal and two in the Free State. For business reasons, it was decided to put the farms on the market. A father and son wished to acquire the farms in a company called Abrina 6822 Limited. The shares in Abrina 6822 Ltd are owned by the Rosco Family Trust, of which Mr Roshen Sewpersad is a trustee and beneficiary. The Sewpersads faced difficulty in acquiring the farms in that they needed finance. The circumstances surrounding the obtaining of finance gave rise to this case.

Referring to the Seevnarayan case, it was held that "a restrictive interpretation should be given to the notion of property being derived, received or retained in connection with, or as a result of, unlawful activities". That court relied on the fact that referring to the title (long or short) of the Act it was directed at the combating of organised crime, money laundering and criminal gang activities. On that basis it held that tax evasion could not be considered organized crime, and that "the Act was never intended to be applied in situations such as the present". However, this basis was rejected by the court in the following ruling of Judge Wallis: "We cannot agree with this construction, which radically truncates the scope of the Act. It leaves out portions of the long title, as well as the ninth paragraph of the preamble. These show that the statute is designed to reach far beyond organised crime, money laundering and criminal gang activities. The Act clearly applies to cases of individual wrong-doing." This judgment by Wallis was reaffirmed by the judgment in NDPP $v$ Van Staden and Others.

The second court case is the case between NDPP v King 2010 (2) SACR 146 (SCA). The respondent, Mr DC King, was indicted on 322 counts, including fraud, tax evasion and evasion of the exchange control regulations, as well as money laundering and racketeering. The counts relate among others to a failure to submit tax returns, fraudulent misrepresentations in his tax returns, and devising and implementing an allegedly fraudulent scheme to 'externalize' his assets to evade income tax and obligations under the regulations, involving amounts in excess of R1 
billion. The main complainant was the South African Revenue Service. It apparently had a claim of some R3 billion against King flowing from some of the allegations.

Lastly - and probably the most famous court case of 2007 to 2009 - was that of NDPP v Zuma 2009 (1) SACR 361 (SCA). Mr Mokotedi Joseph Mpshe, the acting NDPP, decided on 27 December 2007 once again to indict Mr Jacob Zuma (the current president of South Africa). That decision was followed by an indictment of 87 pages with 18 main counts of racketeering, corruption, money laundering, tax evasion and fraud. Much was based on the same subject matter that was dealt with in the Shaik trial but, according to the NDPP, the facts and circumstances differed substantially because the evidence against Mr Zuma had become more compelling and the legal impairments to charging him had been reduced.

In each of the above-mentioned South African court cases, it is clear that wherever there was a count of money laundering brought against the accused, tax evasion was also brought against them. Again it seems that the authorities responsible for charging the perpetrators had, as in the international court cases, already accepted an existing link between tax evasion and money laundering because where there was a count of money laundering, a count of tax evasion was also brought against the accused.

The judgment that most clearly states the link between money laundering and tax evasion is the one made by Wallis $\mathrm{J}$ in Abrina $6822 \mathrm{Ltd}$. In short, he stated that the ninth paragraph of the preamble to the statute (of Prevention of Organised Crime Act) is designed to reach far beyond organized crime, money laundering and criminal gang activities. The Act also undoubtedly applies to cases of individual wrong-doing.

Although individual wrong-doing is a very broad term that can include a magnitude of activities; tax evasion can undoubtedly be included as one too, based on all the definitions that were analyzed in the sections above.

\section{CONCLUSION}

The main aim of this research was to establish whether or not there is a link between tax evasion and money laundering. Relevant literature, legal definitions, court cases, reports published by relevant organizations, scholarly articles and news headlines were studied. Although all of the above-mentioned sources provided valuable information, the source that illustrated the answer to the research question the best, was that of the court case judgments.

The findings in the analysis of definitions on tax evasion and money laundering also proved the link between these two offences. However, for this fact to be validated, the judgment made by Judge Wallis in the South African court case of Abrina $6822 \mathrm{Ltd}$ was found to be the most conclusive answer to the research question. He pronounced that the "ninth paragraph of the preamble to the statute (of Prevention of Organised Crime Act) is designed to reach far beyond organised crime, money laundering and criminal gang activities. The Act also undoubtedly applies to cases of individual wrong-doing". As already mentioned in the last paragraph of the section on court cases, the term "individual wrong-doing" is a very broad term, but in view of the analysis done on the explanation of tax evasion, the act of evading taxes can be added to the definition of 'individual wrong-doing'.

The recommendation derived from the research is that legal authorities should consider investigating the act of evading taxes in addition to their policy of investigating money laundering. Although evidence from the court cases shows that the authorities may already be doing this, it might just be more appropriate to add it officially to their existing policy.

The contribution of this research is the establishment of the link between the offence of money laundering and that of tax evasion. Although this statement can be substantiated by the evidence found in this research, it should still be taken into account that almost no literature could be found that had already connected money laundering to tax evasion. Furthermore, no court case could be found where the accused was found guilty of both tax evasion and money laundering. 
Based on the outcomes of the research and information contained therein, the perception that money makes the world go round is a contentious statement when paired with crimes like money laundering and tax evasion.

\section{AUTHOR INFORMATION}

Ansia Storm was a student for five years at the Northwest University in Potchefstroom, South Africa. After graduation in 2003, she completed her practical training at an accounting firm and received her designation as Professional Accountant (SA) in 2006. In 2004, she enrolled for a master's degree in international and national taxation which she completed in 2005. In 2007, she enrolled for a master's degree in forensic accounting and completed it in 2009. In 2008, she received her designation as Master Tax Practitioner (SA). She is currently a senior lecturer at the Northwest University in Potchefstroom, South Africa. Her main field of study is taxation and forensic accounting. Mrs Ansia Storm, Northwest University, Potchefstroom, South Africa, PO Box 19313, Noordbrug, South Africa, 2522. E-mail: Ansia.Storm@nwu.ac.za

\section{REFERENCES}

1. Al Capone. (2012). The Biography Channel website. Retrieved from: http://www.biography.com/people/alcapone-9237536

2. Al Capone. (2013). The Spartacus Educational website. Retrieved from: http://spartacus.schoolnet.co.uk/USAcapone.htm

3. Bauer, N. (2012). Hawks ready 'to arrest and charge' Malema. The Mail and Guardian. Retrieved from: http://mg.co.za/article/2012-09-02-hawks-ready-to-charge-malema

4. Blake, M \& Pisa, N. (2012). Berlusconi sentenced to four years for tax fraud but will he EVER go to jail? Judge cuts sentence by three quarters with appeal far from over. Mail Online News. Retrieved from: http://www.dailymail.co.uk/news/article-2223603/Silvio-Berlusconi-jailed-years-tax-fraud.html

5. Christensen, J. (2011). The looting continues: tax havens and corruption. Critical Perspectives on International Business. Emerald Group Publishing Limited. Retrieved from:

http://www.emeraldinsight.com/1742-2043.htm

6. Christensen, J. and Hampton, M. (1999b), “A legislature for hire: the capture of the state in Jersey's Offshore Finance Centre", in Hampton, M. and Abbott, J. (Eds), Offshore Finance Centres and Tax Havens: The Rise of Global Capital, Macmillan, Basingstoke, pp. 166-91.

7. Christensen, J. \& Spencer, D. (2008). Comment: Stop this timidity in ending tax haven abuse. Financial Times, 5 March, p. 13.

8. Clark, J. Why was tax evasion the only thing pinned on Al Capone. How Stuff Works. Retrieved from: http://history.howstuffworks.com/history-vs-myth/capone-tax-evasion.htm

9. Conway-Smith, E. (2012). Jacob Zuma: Leaked KPMG report shows S. Africa president was a 'kept politician'. The Telegraph. Retrieved

from:http://www.telegraph.co.uk/news/worldnews/africaandindianocean/southafrica/9730449/Jacob-ZumaLeaked-KPMG-report-shows-S.Africa-president-was-a-kept-politician.html

10. Crumley, B. (2012). It's Official: Eurozone enters Second Recession in Three Years. Time. Retrieved from: http://world.time.com/2012/11/15/its-official-eurozone-enters-second-recession-in-three-years.htm

11. Dadoo, A. Money Laundering. The Global Politician website. Retrieved on October 192012 from http://www.globalpolitician.com/print.asp?id=4153

12. Definition of "Tax Evasion". Retrieved from: http://www.investopedia.com/search/default.aspx?q=Tax\%20Evasion

13. Dugdale, N.W, (2012). Is Reform Possible at a Time of Political Crisis? An Assessment of Greece's Efforts to Combat Tax Evasion and Shadow Economy Participation. CDDRL Stanford.

14. Friedman, E. (2010). Actor Wesley Snipes Reports to Pennsylvania Federal Prison. ABC News. Retrieved from: http://abcnews.go.com/Entertainment/wesley-snipes-report-federal-prison-year-sentence/story?id=12345648

15. Fruitland Bar Owner Charged with Income Tax Evasion and Illegal Gambling. (2011). The United States Attorney's Office: District of Idaho. Retrieved from: http://www.justice.gov/usao/id/news/2011/sept/overstreet09142011.html

16. Income Tax Act No 58 of 1962. 
17. Kar, D \& Freitas, S. (2012). Illicit Financial Flows from Developing Countries: 2001-2010. A December 2012 Report from Global Financial Integrity. Retrieved from: http://iff.gfintegrity.org/iff2012/2012report.html

18. Kleutgens, I., Sambur, J.A., Grieser, S.G. \& Gunther, S. (2011). FATCA - Tax Risks for US Investments. Mayer Brown. Retrieved from: http://www.mayerbrown.com/publications/fatca--tax-risks-for-usinvestments-09-23-2011/

19. Krishna, V. (2008, August 29). The legacy of Al Capone in tax law. The Lawyers' Weekly. Retrieved from http://www.lawyersweekley.ca

20. Legal definition of "Illegal activity". Retrieved from: http://legaldictionary.thefreedictionary.com/illegal+activity

21. Marquit, M. (2012, January 23). What is tax evasion and how it could affect you. Retrieved from http://freefrombroke.com

22. Matheza, T. (2008). Tax Fraud and Money Laundering Today - Lessons from Germany? Retrieved from: http:// www.icpat.org/.../36-tax-fraud-and-money-laundering-today-lessons...

23. Money Laundering. Retrieved from: http://www.austrac.gov.au/elearning/pdf/intro_amlctf_money laundering.pdf

24. Money-Laundering and Globalisation. (2012). The United Nations Office on Drugs and Crime. Retrieved from: http://www.unodc.org/unodc/en/money-laundering/globalization.html

25. Murphy, R. (2011). Tax Evasion costs the World \$3.1 trillion a year - more than 5\% of World GDP. Tax Research UK. Retrieved from: http://www.taxresearch.org.uk/Blog/2011/11/25/tax-evasion-costs-theworld-3-1-trillion-a-year-more-than-5-of-world-gdp/

26. National Director of Public Prosecution v Abrina 6822 Ltd \& others. Retrieved from: http://www.heinonline.org

27. National Director of Public Prosecutions v King 2010(2) SACR 146. Retrieved from: http://www.heinonline.org

28. National Director of Public Prosecutions v Zuma 2009(1). Retrieved from: http://www.heinonline.org

29. O'Leary, N. (2013) Berlusconi trial hearing postponed due to Italian president vote. Reuters. Retrieved from: http://www.reuters.com/article/2013/04/18/us-italy-berlusconi-idUSBRE93H0HZ20130418

30. Oldenburg, A. (2013). Report: Wesley Snipes finishes prison time for tax evasion. Retrieved from: http://www.azcentral.com/thingstodo/celebrities/free/20130405wesley-snipes-finishes-prison-taxevasion.html

31. Oliver, K.E. (2002, June). International Taxation: Tax Evasion as a Predicate Offence to Money Laundering. International Legal Practitioner. Retrieved from http://heinonlinebackup.com

32. O'Toole, J. (2012). Swiss bankers charged in $\$ 1.2$ billion tax fraud. CNNMoney.com. Retrieved from: http://money.cnn.com/2012/01/03/news/swiss_bankers_charged/index.htm

33. Owens, J.P. (2007). Offshore Tax Evasion.The Globalist. Retrieved from: http://www.theglobalist.com/printStoryId.aspx?StoryId=6212

34. Prevention of Organized Crime Act No 122 of 1998.

35. Ping, He. (2010). A typological study on money laundering. Journal of Money Laundering Control. Emerald Group Publishing Limited. Retrieved from: http://dx.doi.org/10.1108/13685201011010182

36. Renner, P. (2012). What are Illicit Financial Flows? KYC Map. Retrieved from: http://kycmap.com/illicit-financial-flows-what-are-illicit-financial-flows-iffs/

37. Samuel, H. (2013). French Budget Minister resigns after Tax Fraud Allegations. The Telegraph. Retrieved from: http://www.telegraph.co.uk > Finance > Economics

38. Snyman, C.R. (2006). Strafreg. Durban: LexisNexis Butterworths.

39. Spies v U.S 317 U.S 492497 (1943). Retrieved from: http://www.heinonline.org

40. Spreutels, J and Grijseels, C. 2000. Interaction between money laundering and tax evasion. Belgian and international measures in the fight against money laundering. Retrieved from: http://www.ctifcfi.be/website/images/EN/pub art/s9T10088.pdf

41. Stinglingh, M \& Koekemoer A.D. et al (2013). Silke: South African Income Tax. Durban: LexisNexis.

42. Tavares, R. (2013, January). Relationship between money laundering, tax evasion and tax havens. Special Committee on Organized Crime, Corruption and Money Laundering (CRIM) 2012 - 2013. Retrieved from: http://www.europarl.europa.eu/meetdocs/2009_2014/documents/crim/dv/tavares_ml_/tavares_ml_en.pdf 
43. Tax Havens Causes Poverty. The Tax Justice Network. Retrieved from: http://www.taxjustice.net/cms/front_content.php?idcatart=2\&lang=1

44. The Cost of Tax Abuse: a briefing paper on the cost of tax evasion worldwide. (2011). The Tax Justice Network. Retrieved from: http://www.taxresearch.org.uk/Blog/2011/11/25/tax-evasion-costs-the-world-31-trillion-a-year-more-than-5-of-world-gdp/

45. Tinkoff v U.S 86, F.2d 868. Retrieved from: http://www.heinonline.org

46. Unger, B. 2009. The Gravity Model for Measuring Money Laundering and Tax Evasion. Paper prepared for the Workshop on Macroeconomic and Policy Implication of Underground Economy and Tax Evasion, February 5-6, 2009 at Bocconi University, Milan Italy. Retrieved from: http://www2.econ.uu.nl/.../unger/.../Unger\%20for\%20BUSATOconference.doc

47. United States v Smith 424F 3d 992. Retrieved from: $\underline{\text { http://www.heinonline.org. }}$ 
NOTES 